\title{
Increasing community income with processing of plastic waste in Helvetia village
}

\author{
Prihatin Lumbanraja ${ }^{1 *}$, Arlina Nurbaity Lubis ${ }^{1}$, Beby Kendida Hasibuan ${ }^{1}$ \\ ${ }^{1}$ Departmen of Management, Faculty of Economics and Business, Universitas Sumatera \\ Utara \\ *Email: Titinlumbanraja@yahoo.com
}

\begin{abstract}
The presence of waste in the environment is the root of many contradictions. Garbage can cause a variety of diseases, moving comfort, mosquito nests, and apart damaged view around. The presence of garbage makes the environment not beautiful. Nevertheless, many people have contributed to make waste increasingly pollute the environment. Scavengers are one of the professions that help plastic waste with low economic potential. While behind the negative side of waste, this can still be optimized by management so as to provide good economic value. Processing waste also encourages the level of monitoring of waste in the environment which makes it more beautiful. The dedication activities that have been carried out raise several issues at once. First is the empowerment of community groups who are scavengers without active groups. Second is increasing public awareness to dispose of garbage in landfills and classifying waste disposal so that it can be better and easier to manage others. Third is pollution caused by unmanaged waste, especially non-organic waste such as plastic. Community service activities help increase the economic and financial activities of partners and groups by helping to start a business as an expertise development that is usually done as a scavenger. Science and technology transfers consisting of management, business management, production management, finance, and groups will be given to partners. In addition, this service is a partner of change that helps change the community so that they are aware of waste disposal. This change will also benefit partners who will more easily obtain raw materials for their production.
\end{abstract}

Keyword: Education, production management, waste management

\begin{abstract}
Abstrak
Kehadiran sampah di Lingkungan merupakan akar dari berbagai pertentangan. Sampah dapat menyebabkan timbulnya berbagai penyakit, berpindah kenyamanan, sarang nyamuk, serta terlepas rusak pemandangan di sekitar. Kehadiran sampah membuat Lingkungan menjadi tidak asri. Kendatipun demikian, banyak masyarakat yang ikut berkontribusi untuk membuat sampah semakin mencemari Lingkungan. Pemulung adalah salah satu profesi yang menolong sampah plastik dengan potensi ekonomi yang rendah. Sementara dibalik sisi negatif dari sampah, hal ini masih dapat dioptimalkan dengan pengelolaan sehingga memberikan nilai ekonomis yang baik. Mengolah sampah juga mendorong pada tingkat pemantauan sampah di lingkungan yang membuatnya lebih asri. Kegiatan pengabdian yang telah dilakukan mengangkat beberapa isu sekaligus. Pertama adalah pemberdayaan kelompok masyarakat yang menjadi pemulung tanpa kelompok yang aktif. Kedua adalah peningkatan kesadaran masyarakat untuk membuang sampah di tempat pembuangan sampah serta melakukan klasifikasi pembuangan sampah sehingga bisa lebih baik dan memudahkan mengelola orang lain. Ketiga adalah pencemaran yang diakibatkan oleh sampah yang tidak dikelola, khususnya sampah non-organik seperti plastik. Kegiatan pengabdian membantu menigkatkan kegiatan ekonomi dan keuangan dari mitra serta kelompoknya dengan membantu memulai usaha sebagai pengembangan keahlian yang biasa dilakukan sebagai pemulung. Transfer ipteks terdiri dari manajemen, manajemen usaha, manajemen produksi, keuangan, serta kelompok akan diberikan kepada mitra. Selain itu pengabdian ini adalah mitra perubahan yang membantu perubahan di lingkungan masyarakat agar sadar akan ada pembuangan sampah. Perubahan ini juga akan menguntungkan mitra yang akan lebih mudah memperoleh bahan baku untuk produksinya.
\end{abstract}

Kata Kunci: Edukasi, manajemen produksi, pengolahan sampah 


\section{PENDAHULUAN}

\subsection{Latar Belakang Kegiatan Pengabdian}

Kesadaran masyarakat akan kesehatan dan keselamatan lingkungan terus menerus berkembang. Hingga saat ini telah banyak program 'save our earth' yang digerakkan oleh masyarakat di belahan Bumi Indonesia. Tujuannya adalah melestarikan keindahan sekaligus memastikan peningkatan kualitas lingkungan sekitar. Banyak komunitas dan non-government organization lainnya sebagai penggerak gerakan penyelamatan lingkungan mempercayai bahwa lingkungan adalah bagian dari kehidupan keseharian kita.

Banyak masyarakat mulai menyadari bahwa menjaga kesehatan dan kebersihan lingkungan menjadi tanggung jawab kita bersama. Keberlangsungan hidup lingkungan yang asri juga berkaitan dengan keberlangsungan kita sebagai masyarakat penghuninya. Permasalahan kesehatan lingkungan yang paling nyata adalah permasalahan seputar keberadaan sampah, baik sampah organik maupun non-organik. Sampah dihasilkan oleh setiap individu, setiap rumah tangga, dalam setiap aktivitas sehari-harinya (Singh et al., 2014). Sampah itu muncul baik dari keperluan konsumsi maupun aktivitas sehari-hari lainnya (Wiesmeth dan Häckl, 2011). Peningkatan jumlah sampah yang dihasilkan tidak sebanding dengan keberadaan tempat sampah yang tersedia. Pada akhirnya, sampah ini akan melebihi kapasitas daya tampung pembuangan sampah dan mencemari 2009).

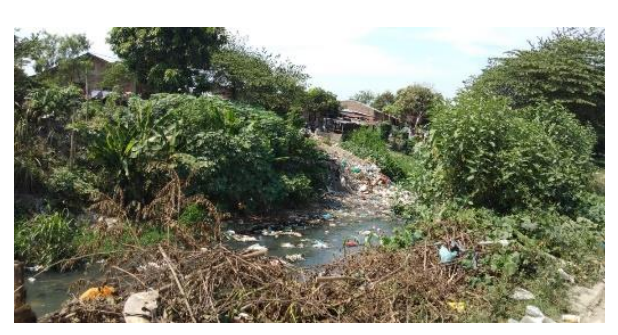
lingkungan (Satterthwaite,

\section{Gambar 1.1 Sampah di Lokasi Mitra}

Kehadiran sampah yang melebihi kapastias akan mulai menimbulkan permasalahan, seperti membawa bibit menyakit ataupun menimbulkan kerusakan pada alam sekitarnya. Sampah organik dapat terurai dan menjadi bagian dari alam serta umumnya akan menjadi nutrisi bagi alam. Sayangnya, sampah non-organik memiliki sifat yang sulit terurai sehingga berkontribusi nyata pada pemanasan global maupun pencemaran lingkungan.

Di balik sisi negatif dari kehadiran sampah pada lingkungan masyarakat, sampah, khususnya sampah plastik dapat menjadi sumber rejeki bagi masyarakat setempat yang mau mengolahnya (Oteng-Ababio, 2011). Pengolahan sampah plastik yang bersifat non-organik ini akan membantu pengurangan pencemaran lingkungan sekaligus membantu ekonomi masyarakat setempat. Sampah plastik diolah sedemikian rupa sehingga dapat dimanfaatkan sebagai biji plastik ataupun plastik cacah yang dapat diolah serta dimanfaatkan kembali ke masyarakat. Hal ini membuat nilai ekonomis dari plastik mengalami peningkatan dan mendorong nilai guna serta nilai ekonomis dari sampah.

Pengabdian yang hendak dilaksanakan ini berkaitan dengan peningkatan ekonomi masyarakat melalui pemanfaatan sampah plastik. Target masyarakat potensial dalam pengelolaan sampah ini adalah pemulung dan komunitasnya yang terbiasa dengan pemungutan sampah plastik (Abrams, 2010). Kehadiran pemulung sebenarnya akan mengurangi intensitas sampah plastik di lingkungan sekitar. Pemulung ini dapat lebih diberdayakan lagi dengan memberikan bantuan ipteks pengelolaan usaha serta alat bantu usaha sehingga mereka menjadi lebih mandiri dan menjadi pelaku usaha berbasis plastik.

\subsection{Permasalahan Mitra}


Dengan mengacu kepada analisis situasi yang telah dilakukan pada masyarakat Desa Helvetia dan kelompok mitra, maka permaslaahan yang hendak diselesaikan pada pengabdian ini meliputi: 1. Masyarakat setempat masih belum secara sadar dan secara nyata melakukan aktivitas pemisalah sampah organik dan non-organik. Keuntungan dari pemisahan sampah ini sebenarnya sangat besar. Selain sampah lebih tertata, pemanfaatan sampah serta pengolahan sampah akan dapat dilakukan dengan lebih baik. Oleh karena itu, pengabdian ini berencana mengangkat isu perubahan pada aktivitas sosial dan membudayakan pemisahan sampah di kalangan masyarakat.

2. Kelompok mitra belum memiliki kemampuan dan kesadaran secara nyata mengenai optimisasi potensi pengolahan sampah sebagai sumber penghasilan usaha berkelompok. Pola pikir mitra sebelumnya adalah memulung dan menyerahkan hasil kerjanya kepada orang lain. Pengabdian ini berupaya membangun kelompok masyarakat yang lebih mandiri serta mampu meningkatkan pendapatan kelompok dari manajemen usaha

3. Kelompok mitra hanya memiliki dasar yang kuat dalam pengembangan usaha kelompok, tanpa memahami ipteks serta seni dalam mengembangkan usaha kelompok. Meskipun demikian, dasar yang kuat ini adalah bekal yang sangat baik dalam mendorong kesuksesan program pengabdian ini melalui pengembangan usaha kelompok yang kokoh.

4. Dari sisi manajemen keuangan, mitra sangat mengalami pemahaman serta ipteks yang kurang dan jauh dari cukup. Mitra secara umum melaksanakan kegiatan pengelolaan keuangan individu. Oleh karena itu diperlukan pengembangan pengetahuan pengelolaan keuangan, khususnya setelah adanya manajemen usaha kelompok dimana sebagian dari pendapatan usaha akan dibedakan antara uang pribadi dan uang kelompok.

Penulis bersama dengan mitra telah melakukan pembicaraan seputar prioritas dan manfaat dari pelaksanaan kegiatan pengabdian kepada masyasrakat yang diajukan. Mitra diupayakan mencapai peningkatan kesejahteraan melalui penigkatan potensi pendapatan. Usaha mitra, selain membangun peningkatan pendapatan bagi masyarakat, juga membantu mengurangi hasil sampah plastik. Dengan kerja sama antara sivitas akademia selaku pemberi transfer ipteks dengan calon pelaku usaha diharapkan program ini akan berjalan dengan baik.

\subsection{Solusi yang Ditawarkan}

Permaslahan utama dari aspek produksi mitra adalah rencana pelaksanaan proses produksi yang akan dilakukan serta hasil yang akan ditawarkan ke masyarakat berupa produk olahan plastik dengan nilai tambah. Kondisi mitra saat ini adalah keahlian dalam pengadaan bahan baku. Dalam pengadaan bahan baku tersebut mitra sekaligus membantu mengurangi intensitas jumlah sampah plastik yang ada di lingkungan masyarakat.

Solusi yang ditawarkan dalam permasalahan ini adalah dengan mengenalkan produk olahan sampah plastik yang nantinya akan dihasilkan oleh mitra kegiatan pengabdian. Mitra juga dibekali pengetahuan seputar proses produksi, mulai dari bahan baku berupa material hingga peralatan yang diperlukan untuk menghasilkan produk tersebut. Tim pengabdian telah berkonsultasi untu pengadaan peralatan pendukung aktivitas produksi tersebut. Sebagai start-up usaha, mitra akan memanfaatkan lokasinya sebagai pusat aktivitas produksi. Tim akan memberikan alat yang dibutuhkan. Mitra bertanggung jawab dalam pengelolaannya untuk menghasilkan nilai tambah dan mendorok aktivitas finansial dari kelompok serta masyarakat setempat. Berdasarkan hasil analisis situasi yang telah dilakukan, aktivitas pengelolaan usaha kelompok ini akan mendorong penghasilan hingga lima kali dari penghasilan yang saat ini dimiliki oleh mitra pengabdian. Manajemen produksi yang baik akan mendorong efektivitas dan efisiensi yang mengoptimalkan penggunaan input menjadi output (Stevensen dan Chuong, 2014). Manajemen kelompok pada hakikatnya merupakan aktivitas untuk mengelola kelompom demi mencapai tujuan tertentu. Manajemen ini dimulai dari proses perencanaan, pengorganisasian, pengarahan, serta pengendalian dari segala aktivitas sehingga tujuan yang telah ditetapkan dapat tercapai dengan baik (Robbins dan Judge, 2013). 
Permasalahan mitra dalam manajemen kelompok adalah keterbatasan ipteks pengetahuan tentang manajemen kelompok. Sisi positifnya adalah keterikatan antara mitra dengan anggotanya saat ini cukup kuat dan adanya unsur kepercayaan di dalamnya. Apabila hal ini dapat dikelola dengan baik, kelompok usaha ini akan dapat berkembang menjadi bagian yang lebih besar lagi. Solusi yang ditawarkan dalam aspek ini adalah penyuluhan berupa transfer ipteks terkait dengan manajemen kelompok serta kegiatan pendampingan sebagai bentuk praktik lapangan yang membiasakan kelompok tersebut tumbuh dan berkembang. Dalam pelaksanaanya, diharapkan mitra akan mengalami konfik pengelolaan kelompok sehingga pembelajaran yang diterapkan menjadi lebih efektif. Dalam hal tidak ada konflik yang berarti terjadi, tim pengabdian akan melakukan simulasi sehingga pembelajaran tenang pengembangan kelompok menjadi lebih efektif.

Permasalahan mitra seputar manajemen keuangan memiliki berbagai aspek yang dapat dikembangkan. Permasalahan utama dari manajemen keuangan ini berkaitan dengan pengelolaan uang usaha kelompok dimana sebagian dari uang tersebut akan digunakan untuk pengembangan usaha dan pengembangan kelompok. Mitra saat ini mencampurkan antara keuangan pribadi dengan keuangan usaha atau dengan kata lain tidak ada pemisah atau perencanaan dalam pengembangan keuangan hasil usaha tersebut.

Solusi yang ditawarkan dalam aspek keuangan ini meliputi transfer ipteks dan kegiatan pendampingan. Sebagia ukuran keberhasilan program, dilakukan evaluasi pada perubahan perilaku mitra. Pengukuran ini dilakukan pada seberapa jauh aspek manajemen keuangan ini diterapkan pada akhir periode pengabdian, meliputi pencatatan, pemisahan, serta perencanaan keuangan dan pengebangan kelompok.

Permasalahan dari aspek sosial bermasyarakat adalah kesadaran masyarakat akan pemisahan atau pengelompokkan sampah berdasarkan sifat terurainya. Sampah yang telah diklasifikasikan akan lebih mudah pengolahannya dalam proses daur ulang sampah. Seluruh sampah organik misalnya, dapat dimanfaatkan untuk pembuatan pupuk atau diuraikan dengan metode lain. Sampah nonorganik seperti plastik akan dapat dimanfaatkan oleh kelompok mitra dalam proses daur ulang atau peningkatan nilai ekonomi sampah plastik sesuai dengan kegiatan pengabdian yang telah direncanakan.

Solusi yang ditawarkan untuk membawa perubahan pada perilaku sosial masyarakat adalah dengan membina kelompok mitra menjadi agent of change. Mereka akan dibina untuk memberikan sosialisasi sembari membangun tempat pembuangan sampah yang memisahkan antara sampah organik dan non-organik. Dengan demikian, kegiatan perubahan perilaku masyarakat ini akan dilakukan secara terus menerus oleh mitra dan kelompoknya. Diharapkan perilaku yang membiasakan pemisahan sampah ini dapat diterapkan dengan baik oleh masyarakat di akhir periode pengabdian.

\section{METODE PELAKSANAAN}

\subsection{Pendekatan Pengabdian}

Metode pendekatan yang dilakukan adalah berdiskusi dengan mitra, membangun konsep manajemen kelompok, mempersiapkan ipteks dan transfer pengetahuan seputar manajemen produksi serta manajemen keuangan usaha. Pendekatan pengabdian ini dilakukan dengamn transfer ipteks melalui sosialisasi, pendampingan, serta pelatihan kepada mitra. Selain itu, dalam upaya mendukung aktivitas produksi dan sosialisasi kepada masyarakat, kegiatan pengabdian ini memberikan dukungan pengadaan alat berupa alat pencacah plastik dan tempat sampah terklasifikasi organik serta non-organik.

Mitra diharapkan dapat memanfaatkan peralatan produksi yang diberikan secara optimal guna dapat meningkatkan nilai dari sampah plastik tersebut. Selain itu mitra juga diminta untuk berpartisipasi dan berperan aktif dalam kegiatan sosialisasi kepada masyarakat guna tercapainya perubahan perilaku di lingkungan masyarakat. Apabila terjadi situasi di luar rencana pengabdian, mitra dapat berkomunikasi dengan tim pengabdian untuk mencari solusi atas situasi yang terjadi. 
Kegiatan ini akan dievaluasi dua bulan setelah peralatan produksi diberikan. Evaluasi dilakukan dengan mendatangi lokasi pengabdian dan melihat proses produksi. Selain itu juga akan dilakukan perhitungan jumlah produksi setiap kali produksi untuk melihat ada atau tidaknya peningkatan jumlah produksi secara berkala.

\section{HASIL DAN PEMBAHASAN}

\subsection{Perilaku Hidup Sehat Masyarakat}

Masyarakat di wilayah sekitar pengabdian pada saat laporan ini ditulis harus senantiasa membaur dengan keberadaan sampah. Interaksi masyarakat dengan sampah yang cukup padat membuat perilaku hidup sehat ini sulit dicapai. Dengan mengacu pada ipteks yang diberikan terkait pro dan kontra keberadaan sampah, kondisi masyarakat masih jauh dari pola hidup sehat.

Kegiatan pengabdian yang dilakukan di wilayah mitra diharapkan mampu membawa perubahan perilaku kehidupan bermasyarakat. Saat ini masyarakat kurang peduli dengan keberadaan sampah di lingkungannya dengan kesan mereka sudah terbiasa dengan lingkungan yang kurang bersih. Akan tetapi, hal ini bukan merupakan prestasi yang diharapkan dari adaptasi masyarakat dengan lingkungan yang kurang bersih. Kegiatan pengabdian ini menargetkan perubahan perilaku masyarakat yang peduli lingkungan dengan tidak membuang sampah sembarangan serta mau melakukan pemilahan sampah guna pengelolaan yang lebih baik lagi ke depannya. Diharapkan masyarakat mau menjadi agent of change dengan mengajak masyarakat lainnya berprerilaku sehat. Tim pengabdian bersama dengan para mahasiswa secara aktif melakukan pendampingan sembari mengajak masyarakat untuk berperilaku hidup sehat. Kondisi ini akan dievaluasi pada akhir kegiatan pengabdian.

\subsection{Manajemen Pengolahan Sampah}

Tim pengabdian menargetkan pertumbuhan kelompok yang menjadi pemanfaat dalam pengelolaan sampah sebagai sumber pendapatan. Sampah pada hakikatnya adalah waste dari aktivitas rumah tangga ataupun perusahaan yang tidak bernilai lagi dan dibuang oleh pemiliknya. Pemanfaatan sampah yang baik akan dapat meningkatkan nilai ekonomi dari masyarakat setempat.

Kondisi mitra pengabdian saat ini menunjukkan aktivitas pengumpul sampah plastik berupa botol plastik yang akan dijual kepada penampung. Manajemen pengolahan sampah yang kurang baik mengakibatkan banyak waste yang tersisa dan membuat tumpukan sampah serta mengganggu kesehatan lingkungan setempat. Sampah dapat dikelola berdasarkan klasifikasi tertentu. Sebagai contoh, sampah rumah tangga berupa sisa sayuran dapat dijadikan makanan ternak ataupun bahan baku pupuk kompos yang dapat dimanfaatkan ataupun dijual kembali. Sampah-sampah plastik dapat dicacah dan didaur ulang. Sampah-sampah besi dapat dijual kembali ke penadah. Sampah-sampah kardus dapat dimanfaatkan untuk berbagai kerajinan.

Manajemen pengelolaan sampah yang baik dan terpadu adalah kunci dalam kegiatan pengabdian ini. Tanpa pengelolaan sampah yang baik, akan sulit bagi masyarakat untuk menciptakan pola hidup sehat dan meningatkan pendapatan masyarakat secara langsung. Sampah yang dialokasikan dengan baik akan menjaga kualitas bahan baku untuk pengolahan sampah itu sendiri sehingga dapat mengurangi waste yang terbuang. Pengalokasian sampah dengan baik juga mempermudah pembuangan dan pembakaran sisa sampah nantinya.

Dalam manajemen pengelolaan sampah yang baik, diperlukan agent of change yang memberikan contoh dan mengajak masyarakat untuk mau bekerja sama ke arah yang lebih baik. Berkaitan dengan hal tersebut, kepedulian mahasiswa sebagai bagian aktif pendampingan diharapkan mampu membawa contoh yang baik ke masyarakat.

\subsection{Peningkatan Pendapatan Masyarakat}


Salah satu tujuan utama dari kegiatan pengabdian ini adalah peningkatan pendapatan masyarakat dari pengolahan sampah yang sebelumnya telah diuraikan. Sampah-sampah yang sudah tidak bernilai ekonomis jika kelola dengan baik akan memberikan nilai ekonomi yang baik kepada masyarakat. Sebagian masyarakat juga memelihara ternak di sekitar rumah mereka yang mendorong alasan tambahan untuk semakin menyukseskan kegiatan pengolahan sampah yang lebih baik lagi.

Tim pengabdian memberikan alat pendukung berupa mesin pencacah plastik sebagai upaya pemberian nilai tambah dari aktivitas ekonomi masyarakat dalam memanfaatkan sampah plastik. Berdasarkan hasil survey yang dilakukan terkait harga pasar untuk sampah plastik ini, pemanfaatan mesin yang diberikan dapat meningkatkan hingga $25 \%$ pendapatan masyarakat. Selain itu, mitra bersama masyarakat juga diajak untuk memperluas cakupan pemanfaatan sampah, bukan hanya sekedar sampah plastik. Mitra sangat antusias dengan pemanfaatan peralatan yang diberikan. Kendala utama dari pemanfaatan ini adalah kebutuhan pasokan air untuk mesin serta terbatasnya jumlah mesin sehingga harus bergantian masyarakat dalam menggunakan mesin yang dimaksud. Untuk menjaga hal tersebut, mitra bertanggung jawab dalam pengelolaannya. Peningkatan pendapatan ini akan dievaluasi kembali pada akhir kegiatan pengabdian.

\subsection{Evaluasi Pelaksanaan Kegiatan}

Kegiatan Pengabdian Pada Masyarakat ini berlangsung dengan baik dan lancar, serta perlu dilakukan pendampingan lebih lanjut dikemudian hari. Proses sosialisasi dan pendampingan berlangsung dengan menarik dan para peserta sangat antusias. Hal ini ditandai dengan banyaknya pertanyaan dari para peserta terkait pengembangan ekonomi kelompok dan pemanfaatan sampah serta terkait pasar untuk olahan sampah plastik hasil cacahan tersebut. Dalam kegiatan ini mitra dan tim berperan aktif dan saling bertukar ide mengenai hal-hal yang menjadi permasalahan mitra dan mencari solusi atas permasalahan yang dihadapi.

Keterlibatan mahasiswa pada aktivitas pengabdian sangat mendorong efisiensi transfer ipteks khususnya pendampingan masyarakat. Mahasiswa dapat membantu pendampingan secara lebih intens di bawah pengawasan tim pengabdian. Kegiatan ini sekaligus melatih mahasiswa dalam kehidupan bermayarakat terkait tanggung jawab dan keilmuan lainnya yang diperolehnya selama perkuliahan.

\subsection{Hambatan yang Dihadapi}

Salah satu target dari aktivitas pengabdian ini adalah perubahan perilaku masyarakat. Kendala utamanya adalah kemauan untuk memulai perubahan tersebut dari lingkungan mitra dan kelompoknya. Masyarakat terlihat sudah beradaptasi dengan baik dengan lingkungan yang kurang sehat. Perubahan lingkungan secara mendasar akan sangat sulit dilakukan tanpa ada kegiatan gotong royong seluruh masyarakat dalam membersihkan lingkungan. Selain itu akses jalan yang sulit membuat banyak warga yang kurang peduli dengan lingkungan. Sebagai solusi dari hambatan implementasi ini, tim pengabdian berupaya untuk menumbuhkembangkan agent of change yang membawa bibit-bibit perubahan, mulai dari mitra dan kelompoknya.

\section{KESIMPULAN}

Kegiatan pengabdian pada masyarakat yang telah dilaksanakan hingga pada tahap laporan akhir mono tahun ini memberikan kesimpulan sebagai berikut:

1. Pemberian alat dan edukasi kepada kelompok mitra memberikan peningkatan pendapatan yang cukup baik. Alat digunakan untuk mengolah sampah plastik menjadi bentuk sampah cacah yang memberikan nilai tambah. Nilai jual olahan sampah umumnya 50\% lebih tinggi dari tanpa dicacah.

2. Masyarakat setempat sudah terbiasa dengan lingkungan berbaur dengan sampah yang dapat mempersulit perubahan perilaku masyarakat. Oleh karena itu, agent of change dalam hal ini sangat dibutuhkan. 
3. Sampah yang digunakan masyarakat untuk pertambahan ekonomi adalah sampah plastik yang mengakibatkan sampah lainnya justru menumpuk di lingkungan sekitar mitra. Hal ini mendorong perlunya perhatian lebih banyak seputar edukasi pengelolaan sampah.

4. Masyarakat tidak memiliki literasi keuangan yang baik dengan keterbatasan bahwa penghasilan dari sampah plastik berperan sebagai penghasilan utama masyarakat.

5. Mitra dan kelompoknya memiliki pengetahuan yang terbatas terhadap akses pasar yang membuatnya relatif rentan terhadap price taker dari penadah sampah yang dikumpulkannya.Dibab ini tuliskan kesimpulan dari hasil kegiatan pengabdian atau penelitian sesuai hasil yang diperoleh. Banyak kesimpulan sesuai dengan banyak tujuan yang dituliskan pada bagian pendahuluan.

\section{UCAPAN TERIMAKASIH}

Terselenggaranya kegiatan pengabdian masyarakat ini serta penulisan jurnal pengabdian masyarakat ini tidak dapat dipisahkan dari dukungan pendanaan Non PNBP Universitas Sumatera Utara dalam Skema Dosen Wajib Mengabdi dengan Surat Perjanjian Penugasan Pengabdian Masyarakat Program Mono Tahun Tahun Anggaran 2019 Nomor :836/UN5.2.3.2.1/PPM/2019 Tanggal 23 Juli 2019. Untuk itu Tim Abdimas Fakultas Ekonomi dan Bisnis USU mengucapkan terima kasih kepada Rektor Universitas Sumatera Utara serta Ketua dan Sekretaris serta staf Lembaga Pengabdian Kepada Masyarakat Universitas Sumatera Utara.

\section{DAFTAR PUSTAKA}

Abrams, R. (2010). Passion to Profits. Tangerang: Azkia Publisher

Oteng-Ababio, M. (2011). The role of the informal sector in solid waste management in the GAMA, Ghana: Challenges andopportunities. Tijdschrift voor Economische en Sociale Geografie 103(4), pp. 412-425

Purnaya, I. (2016). Manajemen Sumber Daya Manusia. Yogyakarta: Andi Offset

Robbins, S.P., dan Judge, T.A. (2013). Organizational Behaviour (15th Edition). New Jersey: Prentice Hall, E-book Edition

Satterthwaite, D. (2009). The implications of population growth and urbanization for climate change. Environment and Urbanization 21, pp. 545-567

Singh, J., Laurenti, R., Sinha, R. and Frostell, B. (2014). Progress and challenges to the global waste management system. Waste Management \& Research 32(9), pp. 800-812.

Stevenson, W. J. dan Chuong S.C. (2014). Manajemen Operasi: Perspektif Asia. Jakarta: Salemba Empat

Wiesmeth, H. and Häckl, D. (2011). How to successfully implement extended producer responsibility: Considerations from an economic point of view. Waste Management \& Research 29: 891-901. 